\title{
Faktor Penerimaan Pengguna Pada E-Learning Dari Perspektif Siswa Sekolah Dasar Berbasis UTAUT Model
}

\author{
Dewi Sekarini*1, Umi Laili Yuhana ${ }^{2}$, Bagus Jati Santoso ${ }^{3}$ \\ ${ }^{1,2,3}$ Departemen Teknik Informatika, Institut Teknologi Sepuluh Nopember, Surabaya, Indonesia \\ e-mail: *11 dewi.sekarini16@mhs.if.its.ac.id, ${ }^{2}$ yuhana@if.its.ac.id, ${ }^{3}$ bagus@if.its.ac.id
}

\begin{abstract}
Abstrak
Pandemi Covid-19 yang menyebar secara luas ke seluruh dunia telah menyebabkan perubahan dalam berbagai aspek kehidupan. Kegiatan penjarakan sosial dan isolasi mandiri menuntut sekolah untuk mengubah metode pembelajaran menjadi pembelajaran daring. Dengan adanya perkembangan teknologi, pembelajaran daring sangat terbantu dengan adanya e-learning. Namun, beberapa masalah dan tantangan timmbul selama diberlakukannya pembelajaran dengan menggunakan e-leanring. Penelitian ini bertujuan untuk mengidentifikasi faktor-faktor yang mempengaruhi penggunaan e-leaning selama pandemi Covid-19 berdasarkan sudut pandang siswa sekolah dasar. Sebuah ekstensi dari The Unified Theory of Acceptance and Use of Technology atau UTAUT diusulkan dengan menambahkan dua faktor tambahan, yaitu namely E-learning Design dan Parental Assistance. Penelitian dilakukan dengan menggunakan kuisioner yang disebarkan secara daring dan sebanyak 217 data dari responden yang berasal dari SD Muhammadiyah 26 Surabaya berhasil dikumpulkan. Data dianalisis dengan menggunakan metode PLS-SEM. Penelitian ini menemukan bahwa Performance Expectancy, Hedonic Motivation, Habit dan Parental Assistance merupakan faktor kunci yang mempengaruhi niat dari siswa untuk mengadopsi e-learning. Selain itu, penelitian ini juga menemukan bahwa Habit adalah faktor kunci yang mempengaruhi Use Behavior siswa sekolah dasar untuk menggunakan e-learning.
\end{abstract}

Kata kunci-UTAUT Model, COVID-19, E-learning, Use Behavior, Penerimaan Pengguna

\begin{abstract}
The Covid-19 outbreak that spread rapidly around the world has changed so many aspects in life. Social distancing and self-isolation activity forced schools to change the learning process into online learning. With the growth of technology, the online learning is helped a lot by the existence of e-learning. However, some problems and challenges arise from doing the learning process using e-learning application. This study aimed to identify the factors that effecting the use of e-learning during Covid-19 pandemic from the perspective of elementary school students. An extended of The Unified Theory of Acceptance and Use of Technology or UTAUT model is proposed with two additional factors, namely E-learning Design and Parental Assistance. The study was conducted through an online questionnaire and 217 records from respondents, who are students of SD Muhammadiyah 26 Surabaya, were collected. The data is analyzed by PLS-SEM method. This study found that Performance Expectancy, Hedonic Motivation, Habit and Parental Assistance are the key factors which impact the students' intention to adopt e-learning. Moreover, this study also found that Habit is a key factor that effect the Use Behavior of e-learning among elementary school students.
\end{abstract}

Keywords-UTAUT Model, COVID-19, E-learning, Use Behavior, User Acceptance 


\section{PENDAHULUAN}

$P^{\mathrm{e}}$ enggunaan teknologi informasi pada masa sekarang, tidak dapat dipisahkan dari kehidupan manusia. Salah satu efek yang timbul dari penggunaan teknologi pada bidang pendidikan adalah adanya penggunaan media belajar elektronik, yaitu e-learning, di sekolah. E-learning dapat didefinisikan sebagai sebuah teknologi yang dapat memungkinkan sebuah organisasi untuk mengurangi biaya dan meningkatkan ketersediaan pembelajaran [1]. Penggunaan $e$ learning di universitas dan pendidikan lanjut mengalami peningkatan pada beberapa tahun terakhir [2]. Di Indonesia, peningkatan penggunaan e-learning pada pendidikan dasar terjadi setelah diberlakukannya Kurikulum 2013, dimana siswa diharuskan untuk menjadi lebih aktif dalam mengikuti proses pembelajaran.

Pada awal tahun 2020, pandemi Covid-19 muncul dan menyebar secara cepat ke seluruh dunia, sehingga menuntut masyarakat untuk melakukan kegiatan penjarakan sosial dan isolasi mandiri guna memutus rantai penyebaran virus. Maka dari itu, pembelajaran di sekolah dialihkan ke pembelajaran secara daring dari rumah masing-masing. Di Indonesia, pembelajaran secara daring dilakukan daneng dua cara, yaitu secara sinkronus dan asinkronus [3]. Pembelajaran sinkronus adalah proses pembelajaran yang dilakukan dengan memanfaatkan sebuah media yang dapat digunakan untuk oleh guru dan siswa untuk berinteraksi. Sedangkan, pembelajaran asinkronus adalah proses pembelajaran yang dilakukan secara terpisah dengan memanfaatkan media seperti e-learning, baik untuk memberikan materi pembelajaran maupun melakukan evaluasi. Hal ini menjadikan e-learning sebagai properti penting yang menentukan keberhasilan proses pembelajaran daring.

Karena adanya perubahan mendadak dari pembelajaran di sekolah ke pembelajaran daring, ada beberapa masalah dan tantangan yang timbul selama dilakukannya kegiatan pembelajaran [4]. Berdasarkan penelitian yang dilakukan oleh [3], permasalahan tersebut antara lain ketidakstabilan akses internet dan paket internet seluler yang mahal. Selain itu, tantangan dalam menggunakan pembelajaran berbasis daring antara lain adalah dibutuhkannya tingkat disiplin diri yang tinggi dan tuntutuan kepada siswa untuk mendedikasikan lebih banyak waktu untuk mempelajari materi pelajaran [5].

Mengingat pentingnya peran e-learning dalam menentukan keberhasilan pembelajaran daring selama pandemi, dibutuhkan sebuah penelitian untuk menyelidiki faktor-faktor yang menentukan penerimaan teknologi e-learning di kalangan siswa. Sejumlah penelitian telah dilakukan untuk mengidentifikasi dan menganalisis faktor-faktor yang menentukan penerimaan teknologi e-learning di kalangan pelajar, baik sebelum pandemi Covid-19 berlangsung maupun pada masa pandemi berlangsung. Penelitian-penelitian sebelumnya telah menerapkan berbagai model untuk mengidentifikasi berbagai faktor yang menentukan penerimaan pengguna atau user acceptance pada $e$-learning baik di sebuah organisasi maupun tingkat individu [6]-[8]. Namun, sebagian besar studi yang telah ada melakukan penelitian dari sudut pandang mahasiswa atau karyawan dalam sebuah organisasi. Saat ini, belum ditemukan adanya penelitian yang membahas terkait penerimaan teknologi e-learning di kalangan siswa SD, padahal siswa sekolah dasar adalah salah satu pihak yang terkena dampak diberlakukannya pembelajaran daring yang diakibatkan oleh pandemi. Apalagi, secara umum, mahasiswa dan siswa sekolah dasar memiliki karakteristik yang sangat berbeda, seperti mahasiswa memiliki motivasi yang lebih untuk belajar mandiri. Dengan demikian, terdapat kemungkinan bahwa mahasiwa dan siswa sekolah dasar memiliki faktor yang menentukan penerimaan teknologi e-learning yang berbeda dengan satu sama lain. 
Penelitian ini melakukan sebuah eksperimen untuk mengetahui niat dan perilaku penggunaan aplikasi e-learning dari siswa sekolah dasar di Indonesia dengan menggunakan sebuah ekstensi dari model UTAUT. Model UTAUT dipilih sebagai model dasar penelitian karena UTAUT dianggap sebagai sebuah teori penerimaan teknologi yang telah dikembangkan dengan baik, diperbarui, dan relevan oleh para peneliti, karena merupakan gabungan dari teoriteori penerimaan teknologi yang telah diakui sebelumnya [9]. Ekstensi dari UTAUT model yang diusulkan dalam penelitian ini merupakan model yang berbasis UTAUT2 yang ditambah dengan dua faktor baru yaitu faktor E-learning Design dan Parental Assistance. Kedua faktor ini ditambahkan untuk memahami perilaku penggunaan berdasarkan karakteristik siswa SD. Diharapkan, penelitian ini dapat dijadikan referensi oleh sekolah atau pihak yang berwenang untuk membuat atau meningkatkan sistem e-learning untuk jangka panjang.

\section{TINJAUAN PUSTAKA}

\subsection{Unified Theory of Acceptance Model (UTAUT)}

The Unified Theory of Acceptance and Use of Technology atau UTAUT merupakan sebuah model yang digunakan untuk mengidentifikasi niat pengguna ketika menerima teknologi baru atau User Acceptance [10]. Model ini dikembangkan dengan mengintegrasikan delapan teori yang telah ada sebelumnya, seperti Theory of Reasoned Action (TRA), The Motivational Model, The Theory of Planned Behavior (TPB), Technology Acceptance Model (TAM), gabungan TBP/TAM, Innovation Diffusion Theory (IDT), The Model of PC Utilization, dan Social Cognitive Theory (SCT). Model ini telah digunakan dalam studi di banyak bidang, seperti sistem informasi, pemasaran, psikologi, dan bidang manajemen [11].

Teori ini memiliki empat faktor kunci atau konstruk yang menentukan perilaku penggunaan pengguna yang disebut sebagai konstruksi. Keempat konstruk tersebut antara lain, Performance Expectancy (PE), Effort Expectancy (EE), Social Influence (SI), dan Facilitating Condition (FC). Performance Expectancy adalah tingkat di mana seseorang meyakini bahwa ia menggunakan sebuah sistem, maka ia akan memperoleh kinerja yang lebih baik untuk pekerjaannya. Effort Expectancy adalah derajat kemudahan dalam menggunakan suatu sistem. Social Influence adalah tingkat di mana orang-orang penting disekitar pengguna percaya bahwa penggunaan teknologi itu penting. Facilitating Conditions adalah tingkat di mana individu percaya bahwa infrastruktur baik secara organisasional maupun teknis ada untuk mendukung penggunaan sistem. Selain empat konstruksi kunci ini, model UTAUT percaya bahwa faktor moderasi seperti Age atau usia, Gender atau jenis kelamin, Experience atau pengalaman, dan Voluntariness of Use atau kesukarelaan penggunaan juga memengaruhi niat seseorang untuk menggunakan teknologi. Diagram dari model UTAUT1 tertera pada Gambar 1. 


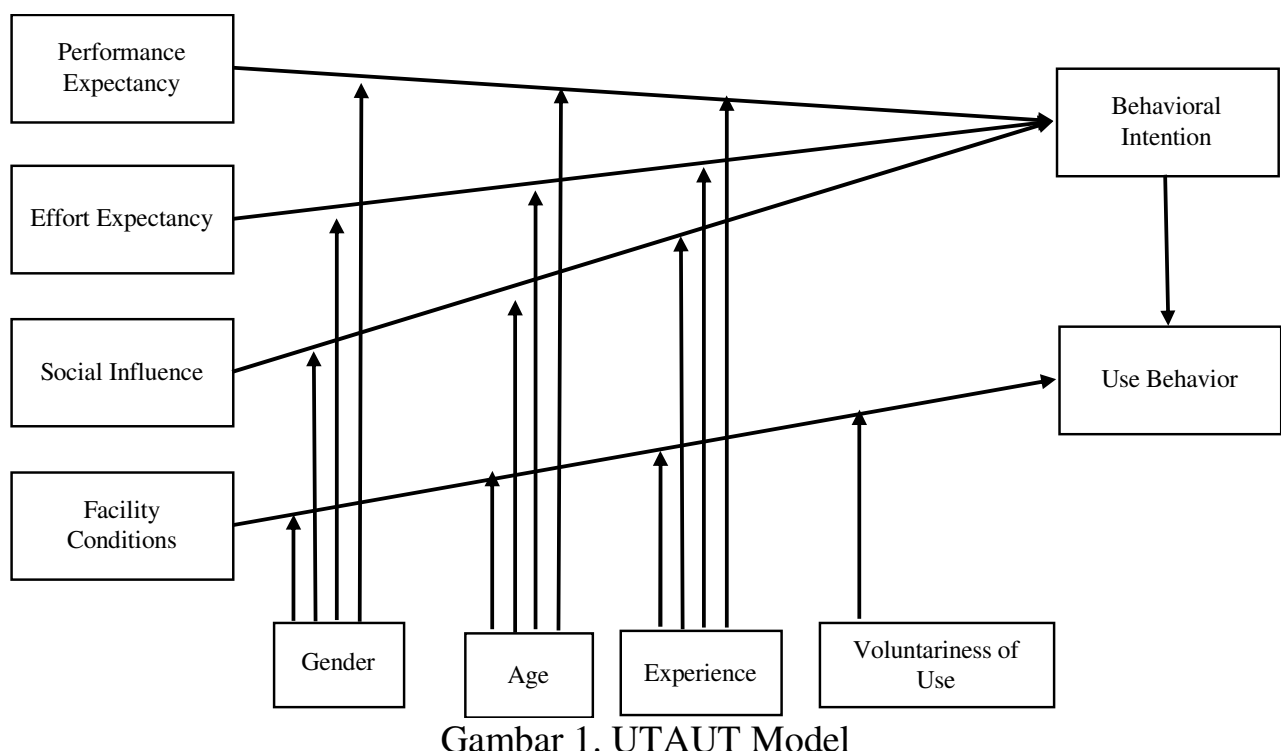

Pada tahun 2012, telah dilakukan penelitian [12] tentang pengembangan dari ekstensi model UTAUT yang menghasilkan UTAUT2. UTAUT2 menambahkan tiga konstruksi kunci baru, yaitu Hedonic Motivation (HM), Habit (H), dan Prive Value (PC). Model ini menjelaskan penerimaan pengguna terhadap teknologi dari perspektif pengguna dengan mengalami peningkatan substansial dalam penjelasan nilai varians untuk Behavioral Intention $(56 \%$ menjadi 74\%) dan Use Behavior (40\% menjadi 52\%) [12]. Gambar model UTAUT2 dapat dilihat pada Gambar 2.

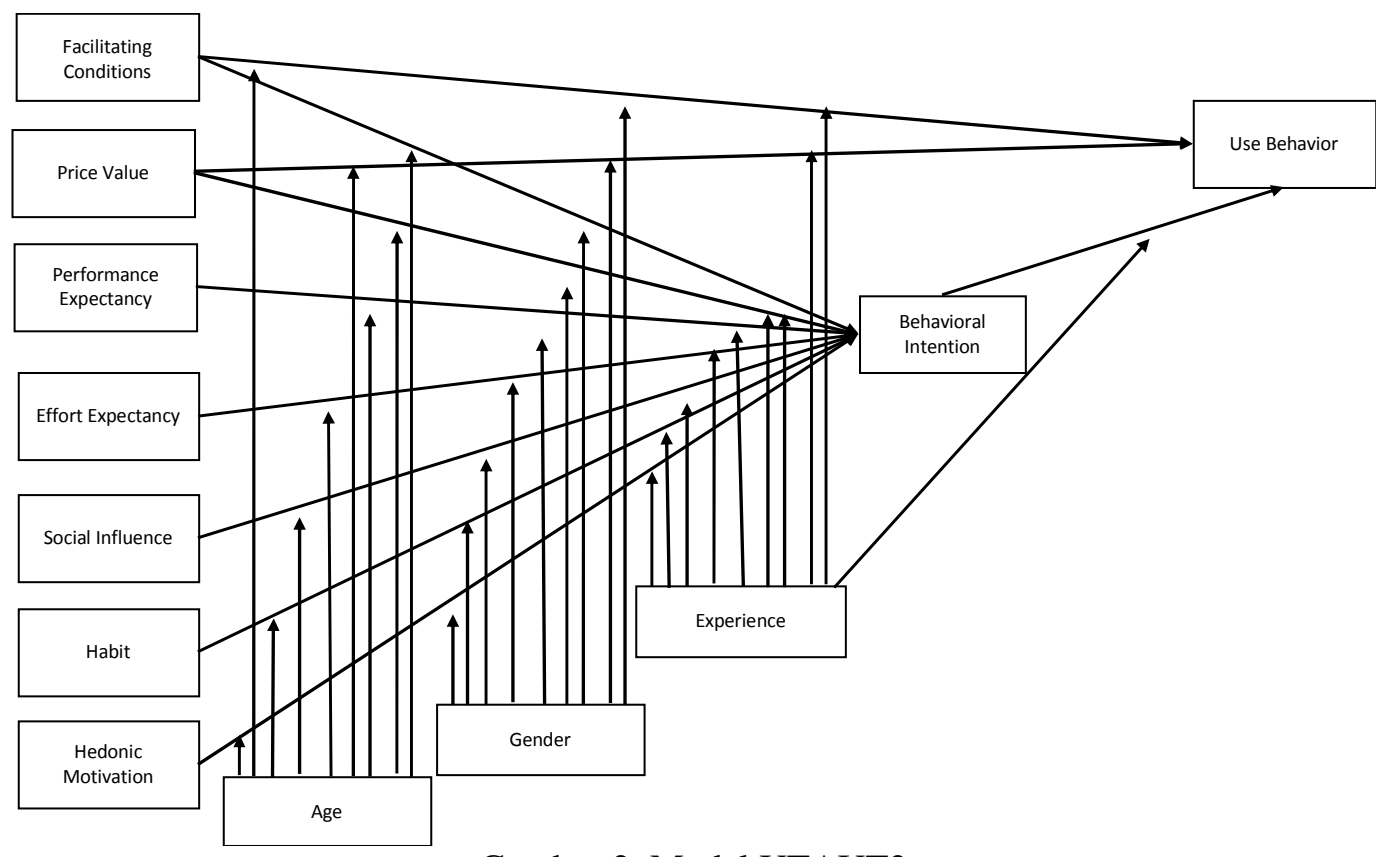

Gambar 2. Model UTAUT2 


\subsection{Analisis PLS-SEM (Partial Least Square- Structural Equation Modelling)}

Structural Equation Modelling atau biasa disebut SEM merupakan sebuah teknik pemodelan statistik yang memiliki sifat linear dan general [13]. Yang termasuk dalam SEM antara lain adalah factor analysis, path analysus dan regression. Salah satu model dari SEM adalah Partial Least Square Structural Equation Modelling atau PLS-SEM. Metode PLS-SEM digunakan pada penelitian ini karena PLS-SEM lebih sesuai digunakan untuk memprediksi konstruk kunci dan memvalidasi sebuah ekstensi dari teori yang telah ada sebelumnya [14].

Di dalam PLS-SEM, model dibagi menjadi dua bagian, yaitu outer model dan inner model. Inner model atau structural model, merupakan bagian yang berfungsi untuk menampilkan hubungan antara konstruksi atau faktor yang akan dievaluasi. Outer model, atau measurement model, merupakan bagian yang digunakan untuk mengevaluasi hubungan antara variabel indikator dan konstruksi yang berhubungan [15]. Untuk menguji outer model, dilakukan dengan 3 tahap yaitu, evaluasi nilai loading factor, convergent validity, dan construct reliability. Sedangkan, evaluasi inner model dilakukan dengan cara melakukan uji coefficient of determination.

\section{HIPOTESIS PENELITIAN}

Penelitian ini bermaksud untuk melakukan proses identifikasi terkait faktor-faktor yang mempengaruhi penerimaan pengguna terhadap teknologi e-learning pada siswa sekolah dasar. Penelitian ini mengusulkan model penyuluhan berbasis UTAUT2. Dalam penelitian ini, Price Value tidak dicantumkan karena e-learning yang digunakan dianggap sebagai aplikasi gratis. Selain itu, faktor moderasi juga tidak dipertimbangkan dalam penelitian ini karena penelitian ini hanya bertujuan untuk mengetahui faktor-faktor yang menentukan penerimaan pengguna teknologi e-learning. Gambar 3 merupakan model ekstensi UTAUT yang diusulkan dalam penelitian ini.

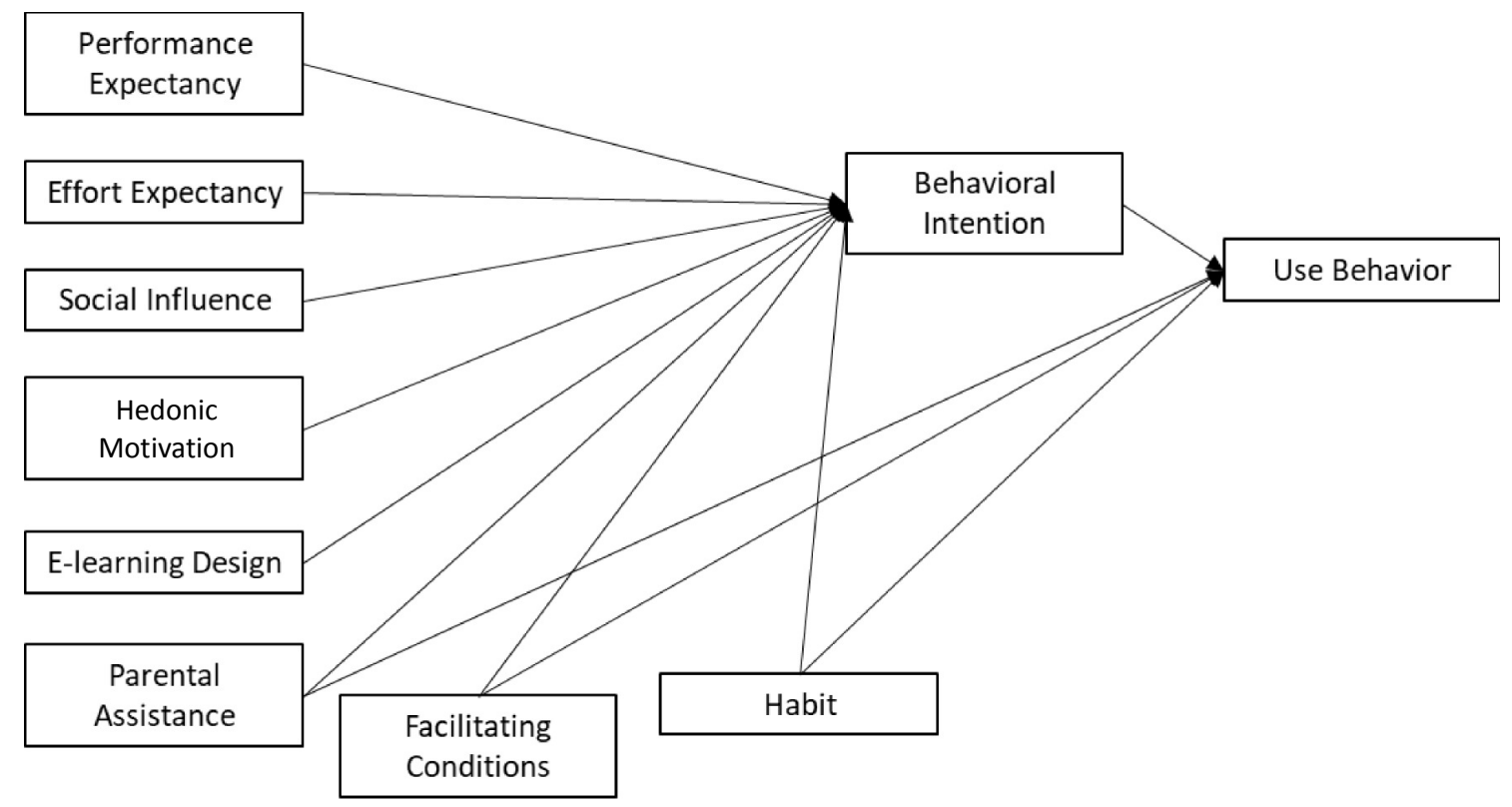

Gambar 3. Kerangka Penelitian yang Digunakan 


\subsection{Performance Expectancy $(P E)$}

Beberapa penelitian membuktikan bahwa Performance Expectancy merupakan faktor yang penting untuk menentukan keinginan seseorang dalam menggunakan teknologi [16], [17]. Sehingga, hipotesis untuk faktor Performance Expectancy adalah:

H1. Performance Expectancy mempunyai efek positif signifikan terhadap Behavioral Intention

\subsection{Effort Expectancy $(E E)$}

Beberapa penelitian mengklaim bahwa Effort Expectancy memberikan efek positif terhadap keinginan seseorang untuk menggunakan teknologi [17], [18]. Sehingga, hipotesis yang diusulkan untuk faktor Effort Expectancy adalah:

H2. Effort Expectancy mempunyai efek positif signifikan terhadap Behavioral Intention

\subsection{Social Influence (SI)}

Dalam penelitian ini, Social Influence mengacu pada derajat dari keinginan individu untuk mengadopsi suatu teknologi karena adanya pengaruh orang lain, seperti teman, guru, dan anggota keluarga. Hipotesis untuk Social Influence yang diajukan adalah:

H3. Social Influence mempunyai efek positif signifikan terhadap Behavioral Intention

\subsection{Facilitating Conditions (FC)}

Facilitating Conditions dapat diartikan sebagai alat yang digunakan atau disediakan untuk mengakses e-learning, seperti laptop, komputer, smartphone, dan koneksi internet. Model UTAUT mengklaim Facilitating Conditions hanya berdampak pada Use Behavior seseorang dalam menggunakan teknologi [10]. Namun, beberapa penelitian membuktikan bahwa Facilitating Conditions juga memiliki pengaruh pada Behavioral Intention seseorang [19], [20]. Sehingga, hipotesis untuk faktor Facilitating Conditions yang diusulkan adalah:

H4a. Facilitating Conditions mempunyai efek positif signifikan terhadap Behavioral Intention H4b. Facilitating Conditions mempunyai efek positif signifikan terhadap Use Behavior

\subsection{Hedonic Motivation (HM)}

Penelitian yang dilakukan oleh [12] dan [21] menunjukkan bahwa Hedonic Motivation juga mempengaruhi Behavioral Intention seseorang untuk menggunakan sebuah teknologi. Sehingga, hipotesis yang diusulkan untuk Hedonic Motivation adalah:

H5. Hedonic Motivation mempunyai efek positif signifikan terhadap Behavioral Intention

\subsection{Habit $(H)$}

Berdasarkan model UTAUT2, Habit mempunyai efek terhadap Behavioral Intention dan Use Behavior. Hipotesis yang diusulkan untuk faktor ini adalah:

H6a. Habit mempunyai efek positif signifikan terhadap Behavioral Intention

H6b. Habit mempunyai efek positif signifikan terhadap Use Behavior

\subsection{Behavioral Intention (BI)}

Behavioral Intention mengacu pada niat individu untuk mengadopsi penggunaan teknologi tertentu untuk melakukan berbagai pekerjaan [22]. Hipotesis untuk konstruk Behavioral Intention adalah:

H7. Behavioral Intention mempunyai efek positif signifikan terhadap Use Behavior 


\subsection{Parental Assistance (PA)}

Keterlibatan orang tua dalam proses pendidikan siswa dimulai di rumah, salah satunya dengan cara menyediakan lingkungan yang aman dan sehat, pengalaman belajar yang sesuai, dukungan dan sikap positif tentang sekolah. [23]. Dalam penelitian ini, konstruk Parental Assistance diartikan sebagai upaya orang tua untuk mendukung dan mendampingi anaknya selama belajar dengan menggunakan e-learning. Faktor ini ditambahkan sebagai konstruk dalam model ekstensi yang diusulkan karena sejumlah penelitian yang telah dilakukan menunjukkan bahwa keterlibatan orang tua dalam pendidikan siswa berdampak pada kinerja akademik siswa, terutama di lingkungan belajar virtual. [24]-[26]. Sehingga hipotesis untuk Parental Assistance adalah:

H8a. Parental Assistance mempunyai efek positif signifikan terhadap Behavioral Intention H8b. Parental Assistance mempunyai efek positif signifikan terhadap Use Behavior

\subsection{E-learning Design (ED)}

Berdasarkan studi yang dilakukan oleh [27], ada beberapa karakteristik yang harus dimiliki e-learning untuk siswa sekolah dasar. Ciri-ciri tersebut antara lain interaktivitas aplikasi, desain yang warna-warni, dan ilustrasi yang menarik. Penelitian ini memiliki tujuan untuk menemukan adanya hubungan antara desain e-learning dengan penerimaan pengguna pada siswa sekolah dasar. Oleh karena itu, hipotesis yang diajukan adalah:

H9. E-learning Design mempunyai efek positif signifikan terhadap Behavioral Intention

\section{METODOLOGI PENELITIAN}

\subsection{Desain Kuisioner}

Studi ini mengaplikasikan metode kuantitatif dengan survei secara daring. Kuesioner yang dibangun dalam penelitian ini terdiri dari dua bagian. Bagian pertama terdiri dari pertanyaan-pertanyaan yang berkaitan dengan informasi demografis seperti nama, usia, jenis kelamin, dan kelas. Bagian kedua terdiri dari 37 item angket skala Lickert dengan skala 1 sampai 5 yang 1 berarti sangat tidak setuju dan 5 berarti sangat setuju. 37 item ini merupakan kompilasi dari pertanyaan penelitian UTAUT sebelumnya dan beberapa penelitian terkait dukungan orang tua dalam pendidikan dan desain e-learning untuk anak-anak. Referensi untuk item kuesioner tercantum dalam Tabel 1. Dari pengumpulan item kuisioner tersebut, didapatkan sebanyak 37 indikator atau item kuisioner yang digunakan pada penelitian.

Tabel 1. Referensi Item Kuisioner

\begin{tabular}{|l|c|}
\hline \multicolumn{1}{|c|}{ Konstruk } & Referensi \\
\hline Performance Expectancy (PE) & {$[8],[16],[28]$} \\
\hline Effort Expectancy (EE) & {$[29]$} \\
\hline Social Influence (SI) & {$[8]$} \\
\hline Facilitating Condition (FC) & {$[8],[28]$} \\
\hline Hedonic Motivation (HM) & {$[30]$} \\
\hline Habit (H) & {$[31]$} \\
\hline Parental Assistance (PA) & {$[32],[33]$} \\
\hline E-learning Design (ED) & {$[27],[34]$} \\
\hline Behavioral Intention (BI) & {$[8]$} \\
\hline Use Behavior (UB) & {$[35]$} \\
\hline
\end{tabular}

Sekarini, et., al [Faktor Penerimaan Pengguna pada E-Learning dari Perspektif Siswa Sekolah Dasar Berbasis UTAUT Model 


\subsection{Pengumpulan Data}

Pengambilan data pada penelitian ini menggunakan SD Muhammadiyah 26 Surabaya sebagai target dari studi kasusnya. Responden merupakan siswa sekolah dasar SD Muhammadiyah 26 Surabaya yang terdiri dari siswa kelas 1 - 6 SD. SD Muhammadiyah 26 Surabaya dipilih sebagai peserta penelitian ini karena sekolah ini telah menerapkan e-learning sebagai media pembelajaran di masa pandemi Covid-19. Kuesioner disebarkan secara daring melalui aplikasi perpesanan dengan bantuan para guru.

\section{HASIL DAN PEMBAHASAN}

Setelah melakukan pengambilan data dengan menggunakan kuisoner daring yang dibuka selama satu bulan, penelitian ini mendapatkan responden sebanyak 217 data yang dianggap valid. Adapun profil dari responden terdapat pada Tabel 2.

Tabel 2. Profil Responden

\begin{tabular}{|c|l|c|c|}
\hline Kategori & Keterangan & Jumlah & Persentase \\
\hline \multirow{3}{*}{ Jenis Kelamin } & Laki-laki & 106 & $48.84 \%$ \\
\cline { 2 - 4 } & Perempuan & 111 & $51.16 \%$ \\
\hline \multirow{5}{*}{ Kelas } & 1 & 22 & $10.14 \%$ \\
\cline { 2 - 4 } & 2 & 16 & $7.37 \%$ \\
\cline { 2 - 4 } & 3 & 30 & $13.82 \%$ \\
\cline { 2 - 4 } & 4 & 33 & $15.21 \%$ \\
\cline { 2 - 4 } & 5 & 62 & $28.57 \%$ \\
\cline { 2 - 4 } & 6 & 54 & $24.88 \%$ \\
\hline \multirow{5}{*}{ Usia } & 6 & 2 & $0.92 \%$ \\
\cline { 2 - 4 } & 7 & 20 & $9.22 \%$ \\
\cline { 2 - 4 } & 8 & 33 & $5.99 \%$ \\
\cline { 2 - 4 } & 9 & 35 & $15.21 \%$ \\
\cline { 2 - 4 } & 10 & 63 & $29.13 \%$ \\
\cline { 2 - 4 } & 11 & 9 & $19.35 \%$ \\
\cline { 2 - 4 } & 12 & & \\
\cline { 2 - 4 } & 13 & & \\
\hline
\end{tabular}

Penelitian ini menggunakan metode PLS-SEM untuk menganalisis data yang diperoleh dengan bantuan aplikasi SmartPLS 3. Metode ini dipilih karena PLS-SEM lebih cocok digunakan untuk memprediksi konstruksi kunci dan untuk memvalidasi sebuah ekstensi dari model yang ada [14]. Proses analisis dilakukan melalui tiga tahap, yaitu pengujian reliabilitas dan validitas model, pengukuran Coefficient of Determination $\left(\mathrm{R}^{2}\right)$, dan pengujian hipotesis.

\subsection{Pengujian Reliabilitas dan Validitas}

Langkah pertama untuk mengukur reliabilitas dan validitas model adalah mengukur loading factor dari setiap indikator. Suatu indikator harus memiliki loading factor lebih besar sama dengan 0,5 untuk dianggap valid. Indikator dengan loading factor $<0,5$ harus dibuang. Hasil pengujian nilai loading factor model tertera pada Tabel 3. 
Tabel 3. Evaluasi Nilai Loading Factor

\begin{tabular}{|c|c|c|c|c|c|}
\hline Indikator & Loading Factor & Keterangan & Indikator & Loading Factor & Keterangan \\
\hline PE1 & 0.645 & Valid & HM3 & 0.888 & Valid \\
\hline PE2 & 0.836 & Valid & ED1 & 0.881 & Valid \\
\hline PE3 & 0.749 & Valid & ED2 & 0.853 & Valid \\
\hline PE4 & 0.806 & Valid & ED3 & 0.664 & Valid \\
\hline EE1 & 0.741 & Valid & ED4 & 0.492 & Tidak Valid \\
\hline EE2 & 0.739 & Valid & ED5 & 0.827 & Valid \\
\hline EE3 & 0.672 & Valid & PA1 & 0.782 & Valid \\
\hline FC1 & 0.7 & Valid & PA2 & 0.753 & Valid \\
\hline FC2 & 0.654 & Valid & PA3 & 0.706 & Valid \\
\hline FC3 & 0.694 & Valid & PA4 & 0.754 & Valid \\
\hline FC4 & 0.638 & Valid & PA5 & 0.427 & Tidak Valid \\
\hline SI1 & 0.813 & Valid & BI1 & 0.832 & Valid \\
\hline SI2 & 0.873 & Valid & BI2 & 0.768 & Valid \\
\hline H1 & 0.661 & Valid & BI3 & 0.745 & Valid \\
\hline H2 & 0.769 & Valid & BI4 & 0.869 & Valid \\
\hline H3 & 0.774 & Valid & UB1 & 0.896 & Valid \\
\hline H4 & 0.828 & Valid & UB2 & 0.65 & Valid \\
\hline HM1 & 0.893 & Valid & UB3 & 0.687 & Valid \\
\hline HM2 & 0.89 & Valid & & & \\
\hline
\end{tabular}

Dari Tabel 3, dapat dilihat bahwa dari 37 indikator terdapat 2 indikator yang dianggap tidak valid karena memiliki nilai loading factor yang kurang dari 0.5, yakni indikator ED4 dengan nilai outer loading 0.492 dan PA5 dengan nilai outer loadings 0.427 . Menurut kriteria penilaian metode PLS-SEM, indikator yang dianggap tidak valid patut dihilangkan dari model karena dianggap tidak dapat mengukur konstruk atau variabel laten asosiasinya. Penghapusan indikator akan dilanjutkan dengan melakukan estimasi ulang. Hasil pengujian ulang loading factor dari model terdapat pada Tabel 4.

Tabel 4. Hasil Estimasi Ulang Nilai Loading Factor

\begin{tabular}{|c|c|c|c|c|c|}
\hline Indikator & $\begin{array}{c}\text { Loading } \\
\text { Factor }\end{array}$ & Keterangan & Indikator & $\begin{array}{c}\text { Loading } \\
\text { Factor }\end{array}$ & Keterangan \\
\hline PE1 & 0.645 & Valid & HM2 & 0.89 & Valid \\
\hline PE2 & 0.836 & Valid & HM3 & 0.888 & Valid \\
\hline PE3 & 0.749 & Valid & ED1 & 0.892 & Valid \\
\hline PE4 & 0.806 & Valid & ED2 & 0.863 & Valid \\
\hline EE1 & 0.741 & Valid & ED3 & 0.641 & Valid \\
\hline EE2 & 0.738 & Valid & ED5 & 0.833 & Valid \\
\hline EE3 & 0.672 & Valid & PA1 & 0.802 & Valid \\
\hline FC1 & 0.7 & Valid & PA2 & 0.76 & Valid \\
\hline FC2 & 0.654 & Valid & PA3 & 0.702 & Valid \\
\hline FC3 & 0.694 & Valid & PA4 & 0.745 & Valid \\
\hline FC4 & 0.638 & Valid & BI1 & 0.833 & Valid \\
\hline SI1 & 0.813 & Valid & BI2 & 0.768 & Valid \\
\hline SI2 & 0.873 & Valid & BI3 & 0.744 & Valid \\
\hline
\end{tabular}




\begin{tabular}{|c|c|c|c|c|c|}
\hline Indikator & $\begin{array}{c}\text { Loading } \\
\text { Factor }\end{array}$ & Keterangan & Indikator & $\begin{array}{c}\text { Loading } \\
\text { Factor }\end{array}$ & Keterangan \\
\hline H1 & 0.661 & Valid & BI4 & 0.869 & Valid \\
\hline H2 & 0.769 & Valid & UB1 & 0.896 & Valid \\
\hline H3 & 0.774 & Valid & UB2 & 0.648 & Valid \\
\hline H4 & 0.828 & Valid & UB3 & 0.687 & Valid \\
\hline HM1 & 0.893 & Valid & & & \\
\hline
\end{tabular}

Setelah 35 indikator memiliki nilai loading factor yang dianggap valid, langkah selanjutnya dalam pengujian validitas dan reliabilitas adalah melakukan pengujian pada construct reliability model. Matriks yang digunakan dalam pengujian construct reliability adalah nilai composite reliability. Nilai composite reliability yang dianggap memenuhi kriteria adalah $\geq 0.7$, karena mengindikasikan konstruk memiliki reliabilitas yang dapat diandalkan. Hasil pengujian composite reliability model terdapat pada Tabel 5.

Tabel 5. Nilai Composite Reliability

\begin{tabular}{|c|c|c|}
\hline Konstruk & Composite Reliability & Keterangan \\
\hline PE & 0.846 & Reliabel \\
\hline EE & 0.761 & Reliabel \\
\hline FC & 0.767 & Reliabel \\
\hline SI & 0.831 & Reliabel \\
\hline H & 0.845 & Reliabel \\
\hline HM & 0.92 & Reliabel \\
\hline ED & 0.885 & Reliabel \\
\hline PA & 0.84 & Reliabel \\
\hline BI & 0.88 & Reliabel \\
\hline UB & 0.792 & Reliabel \\
\hline
\end{tabular}

Dari Tabel 5 yang merupakan hasil dari uji composite reliability terlihat bahwa setiap konstruk telah memiliki nilai composite reliability yang lebih dari 0.7 , sehingga semua konstruk pada penelitian ini merupakan konstruk yang reliabel.

Langkah selanjutnya adalah melakukan pengujian validitas konvergen. Validitas konvergen adalah besaran dimana konstruk konvergen untuk untuk menjelaskan variansi dari item-itemnya. Metrik yang digunakan adalah extracted average variance (AVE). AVE yang dianggap valid adalah 0.5 atau lebih besar. Hasil uji AVE yang didapatkan pada penelitian ini terdapat pada Tabel 6 .

Tabel 6. Nilai AVE

\begin{tabular}{|c|c|}
\hline Konstruk & AVE \\
\hline PE & 0.582 \\
\hline EE & 0.515 \\
\hline FC & 0.451 \\
\hline SI & 0.712 \\
\hline H & 0.578 \\
\hline HM & 0.792 \\
\hline ED & 0.661 \\
\hline PA & 0.567 \\
\hline
\end{tabular}




\begin{tabular}{|c|c|}
\hline Konstruk & AVE \\
\hline BI & 0.648 \\
\hline UB & 0.565 \\
\hline
\end{tabular}

Dari Tabel 6, terlihat 9 dari 10 konstruk pada penelitian ini memiliki nilai AVE lebih dari 0.5 Terdapat satu konstruk yang memiliki nilai AVE kurang dari nilai yang direkomendasikan, yaitu konstruk Facilitating Conditions (FC) dengan nilai AVE sebesar 0.451. Berdasarkan prinsip metode PLS-SEM, untuk memperbaiki nilai AVE yang kurang dari nilai minimal, harus dilakukan penghapusan satu indikator pada konstruk dengan nilai loading factor terendah. Berdasarkan Tabel 4, pada konstruk FC, indikator yang memiliki nilai loading factor paling rendah adalah indikator FC4, sehingga indikator tersebut harus dihapus dan harus dilakukan re-estimasi ulang. Hasil re-estimasi dari nilai composite reliability dan AVE terdapat pada Tabel 7.

Tabel 7. Hasil Reestimasi Composite Reliability dan AVE

\begin{tabular}{|c|c|c|}
\hline Konstruk & Composite Reliability & AVE \\
\hline PE & 0.846 & 0.582 \\
\hline EE & 0.761 & 0.515 \\
\hline FC & 0.775 & 0.535 \\
\hline SI & 0.831 & 0.712 \\
\hline H & 0.845 & 0.578 \\
\hline HM & 0.92 & 0.792 \\
\hline ED & 0.885 & 0.661 \\
\hline PA & 0.84 & 0.568 \\
\hline BI & 0.88 & 0.648 \\
\hline UB & 0.789 & 0.561 \\
\hline
\end{tabular}

Tabel 7 menampilkan data yang menunjukkan bahwa nilai composite reliability dan AVE dari setiap konstruk melampaui nilai minimal yang ditentukan yaitu 0.7 dan 0.5 secara berurutan. Sehingga, model dapat dikatakan memenuhi kriteria pengujian validitas dan reliabilitas.

\subsection{Coefficient of Determination $\left(R^{2}\right)$}

Coefficient of Determination $\left(\mathrm{R}^{2}\right)$ merupakan proporsi varians pada variabel dependen yang dapat diprediksi dari variabel independen. Gambar 4 menunjukkan R2 dari dua variabel dependen, Behavioral Intention dan Use Behavior, masing-masing adalah 0,682 dan 0,269. Artinya, delapan variabel laten, Performance Expectancy, Effort Expectancy, Social Influence, Habit, Hedonic Motivation, Facilitating Conditions, E-learning Design, dan Parental Assistance, mampu menjelaskan 68,2\% varians Behavioral Intention. Sedangkan empat variabel yaitu Behavioral Intention, Habit, Facilitating Condition, dan Parental Assistance mampu menjelaskan 26,9\% varians Use Behavior. 


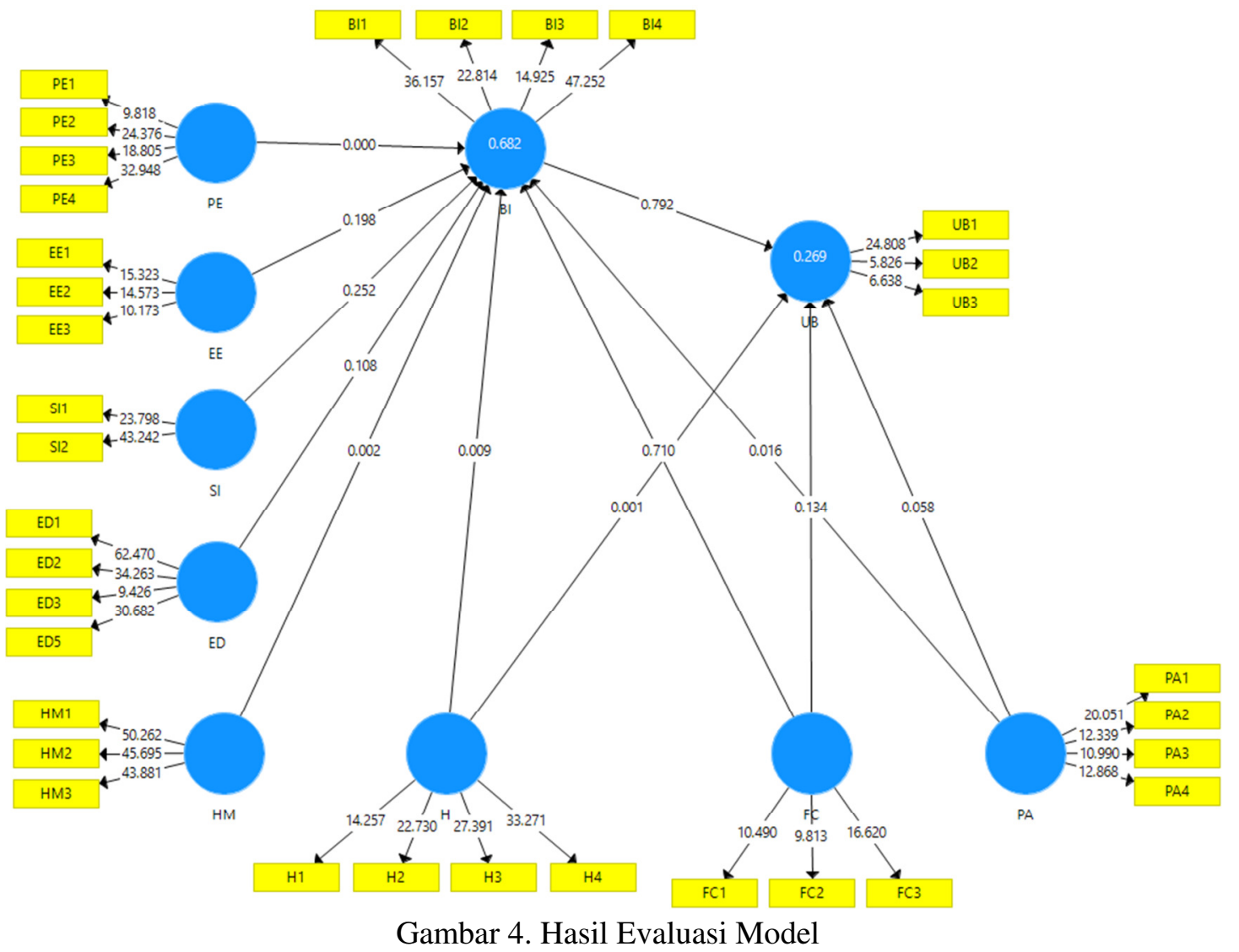

\subsection{Uji Hipotesis}

Dalam penelitian ini menggunakan analisis $t$-test untuk proses pengujian hipotesisnya. Proses Bootstrap dilakukan dengan bantuan aplikasi SmartPLS dengan melakukan uji dua sisi dengan tingkat signifikansi 5\% dan 1000 subsampel. Suatu hipotesis diterima jika memiliki nilai t-test lebih besar dari 1,96 [36] dan p-value lebih kecil dari 0,1. Hasil pengujian hipotesis penelitian ini ditunjukkan pada Tabel 8 .

Tabel 8. Hasil Pengujian Hipotesis

\begin{tabular}{|c|c|c|c|c|}
\hline Hipotesis & Variable & $t$-value & $p$-value & Result \\
\hline H1 & PE $\rightarrow$ BI & 3.706 & 0 & Signifikan \\
\hline H2 & EE $\rightarrow$ BI & 1.288 & 0.198 & Tidak Signifikan \\
\hline H3 & SI $\rightarrow$ BI & 1.145 & 0.252 & Tidak Signifikan \\
\hline H4a & FC $\rightarrow$ BI & 0.372 & 0.71 & Tidak Signifikan \\
\hline H4b & FC $\rightarrow$ UB & 1.499 & 0.134 & Tidak Signifikan \\
\hline H5 & HM $\rightarrow$ BI & 3.154 & 0.002 & Signifikan \\
\hline H6a & H $\rightarrow$ BI & 2.62 & 0.009 & Signifikan \\
\hline H6b & H $\rightarrow$ UB & 3.266 & 0.001 & Signifikan \\
\hline H7 & BI $\rightarrow$ UB & 0.263 & 0.792 & Tidak Signifikan \\
\hline H8a & PA $\rightarrow$ BI & 2.409 & 0.016 & Signifikan \\
\hline H8b & PA $\rightarrow$ UB & 1.895 & 0.058 & Tidak Signifikan \\
\hline H9 & ED $\rightarrow$ BI & 1.607 & 0.108 & Tidak Signifikan \\
\hline
\end{tabular}


Tabel 8 menunjukkan bahwa untuk hipotesis H1, H5, H6a, H6b, dan H8b terjadi adanya keterkaitan atau hubungan positif yang signifikan antara variabel yang berkaitan dengan masing-masin hipotesis. Hal ini dikarenakan setiap hipotesis yang disebutkan di atas memiliki nilai $t$-value $\geq 1.96$ dan $p$-value kurang dari 0.05 yang artinya terdapat hubungan positif dan signifikan terhadap kedua variabel pada masing-masing hipotesis. Sehingga, hal ini sejalan dengan penelitian yang dilakukan oleh [12], [16], [17], [21] bahwa Behavioral Intention, Hedonic Motivation, dan Habit memilki pengaruh positif signifikan terhadap Behavioral Intention, serta Habit juga memilkik pengaruh positif yang signifikan terhadap Use Behavior. Sedangkan, untuk variabel Parental Assistance, Tabel 8 menunjukkan bahwa terdapat hubungan positif signifikan antara PA dengan Behavioral Intention, namun tidak adanya hubugan positif signifikan antar PA dengan Use Behavior. Hal ini menandakan bahwa, semakin intens pendampingan orang tua saat siswa melakukan pembelajaran dengan e-learning, maka semakin meningkat juga keinginan siswa untuk menggunakan e-learning.

Untuk H3, H4a, H4b, dan H10, Tabel 8 menunjukkan bahwa tidak ada hubungan yang signifikan pada variabel pada masing-masing hipotesis. Hipotesis ini dapat terjadi karena penggunaan e-learning untuk siswa SD Muhammadiyah 26 Surabaya bersifat wajib, sehingga Social Influence bukan merupakan faktor yang mempengaruhi niat siswa untuk menggunakan $e$ learning. Sedangkan, untuk variabel Facilitating Conditions yang tidak memiliki hubungan positif signifikan baik terhadap Behavioral Intention maupun Use Behavior, hal ini mungkin terjadi karena siswa menggunakan fasilitas yang sudah disediakan oleh orang tua siswa, sehingga tidak menjadi perhatian mereka saat menggunakan e-learning. Untuk variabel $E$ learning Design, tidak ada hubungan positif signifikan yang terjadi antara variabel ED dengan Behavioral Intention. Hal ini dikarenakan jenis e-learning yang digunakan oleh siswa SD Muhammadiyah 26 Surabaya hanya berjumlah satu aplikasi, sehingga siswa tidak memiliki aplikasi pembanding terkait desain dari aplikasi e-learning. Berdasarkan pembahasan mengenai uji hipotesis di atas, maka rangkuman terkait hasil keputusan uji hipotesis terdapat pada Tabel 9.

Tabel 9. Hasil Uji Hipotesis

\begin{tabular}{|c|c|c|}
\hline Hipotesis & Variable & Hasil Keputusan \\
\hline H1 & PE $\rightarrow$ BI & Diterima \\
\hline H2 & EE $\rightarrow$ BI & Ditolak \\
\hline H3 & SI $\rightarrow$ BI & Ditolak \\
\hline H4a & FC $\rightarrow$ BI & Ditolak \\
\hline H4b & FC $\rightarrow$ UB & Ditolak \\
\hline H5 & HM $\rightarrow$ BI & Diterima \\
\hline H6a & H $\rightarrow$ BI & Diterima \\
\hline H6b & H $\rightarrow$ UB & Diterima \\
\hline H7 & BI $\rightarrow$ UB & Ditolak \\
\hline H8a & PA $\rightarrow$ BI & Diterima \\
\hline H8b & PA $\rightarrow$ UB & Ditolak \\
\hline H9 & ED $\rightarrow$ BI & Ditolak \\
\hline
\end{tabular}




\section{KESIMPULAN}

Penelitian ini bertujuan untuk melakukan identifikasi faktor-faktor yang mempengaruhi penerima pengguna e-learning di masa pandemi Covid-19 berdasarkan perspektif siswa sekolah dasar. Model ekstensi UTAUT yang diusulkan merupakan model yang berdasarkan UTAUT2 dengan dua faktor tambahan, Desain E-learning dan Parental Assistance. Penelitian ini menemukan bahwa Performance Expectancy, Hedonic Motivation, Habit dan Parental Assistance berpengaruh positif signifikan terhadap Behavioral Intention, dan Habit juga berpengaruh positif signifikan terhadap Use Behavior. Dapat disimpulkan, penelitian ini dapat menjelaskan bahwa adopsi teknologi di lingkungan perguruan tinggi dan pendidikan dasar memilki faktor penyebab yang berbeda. Secara umum, model yang diusulkan mampu menjelaskan $68,2 \%$ varians niat siswa dalam mengadopsi e-learning dan $26,9 \%$ varians untuk penggunaan aktual dari e-learning.

\section{SARAN}

Saran yang dapat dilakukan kedepannya dari penelitian ini adalah mengimplementasikan model yang diusulkan pada responden kuisioner dengan demografi yang lebih beragam. Selain itu, faktor moderasi usia dan jenis kelamin dapat digunakan untuk mengetahui apabila apakah ada perbedaan terkait penerimaan pengguna pada kelompok responden yang berbeda.

\section{UCAPAN TERIMA KASIH}

Terima kasih kepada Institut Teknologi Sepuluh Nopember yang telah mendanai penelitian ini dengan Dana Penelitian Flagship Tahun 2021 (No. SK: 1149/PKS/ITS/2021). Sehingga penelitian ini dapat dilakukan dengan lancar dan diharapkan penelitian ini dapat bermanfaat dalam bidang ilmu teknologi informasi.

\section{DAFTAR PUSTAKA}

[1] H. Kong, 2005. "E-Learning: The Quest for Effectiveness Kar-tin Lee," Malaysian Online J. Instr. Technol., Vol. 2, No. 2, pp. 61-71.

[2] M. AL-Lozi, A. Alrowwad, T. Kattoua, M. Al-Lozi Professor of Management, and aldin Alrowwad, 2016. "A Review of Literature on E-Learning Systems in Higher Education," Accessed: Dec. 21, 2020. [Online]. Available: https://www.researchgate.net/publication/309242990.

[3] R. R. Aliyyah, R. Rachmadtullah, and A. Samsudin, 2020, "The Perceptions of Primary School Teachers of Online Learning During The COVID-19 Pandemic Period: A Case Study in Indonesia," doi: 10.29333/ejecs/388.

[4] B. Bakalar, "Book Review: Justice on both sides: Transforming Education Through Restorative Justice,” Am. J. Qual. Res., Vol. 2, No. 2, pp. 145-149, Dec. 2018. 
[5] D. Bouhnik and T. Marcus, 2006, "Interaction In Distance-Learning Courses," J. Am. Soc. Inf. Sci. Technol., Vol. 57, No. 3, pp. 299-305, doi: 10.1002/asi.20277.

[6] S. Hu, K. Laxman, and K. Lee, "Exploring Factors Affecting Academics' Adoption of Emerging Mobile Technologies-An Extended UTAUT Perspective," Educ. Inf. Technol., Vol. 25, No. 5, pp. 4615-4635, Sep. 2020, doi: 10.1007/s10639-020-10171-x.

[7] N. Thongsri, L. Shen, Y. Bao, and I. M. Alharbi, 2018, "Integrating UTAUT and UGT to Explain Behavioural Intention to Use M-Learning: A Developing Country's Perspective,” J. Syst. Inf. Technol., Vol. 20, No. 3, pp. 278-297, doi: 10.1108/JSIT-112017-0107.

[8] V. N. Hoi, 2020, “Understanding Higher Education Learners' Acceptance and Use of Mobile Devices For Language Learning: A Rasch-Based Path Modeling Approach," Comput. Educ., Vol. 146, No. November 2019, p. 103761, doi: 10.1016/j.compedu.2019.103761.

[9] M. Dečman, "Modeling The Acceptance of E-Learning In Mandatory Environments of Higher Education: The Influence of Previous Education and Gender," Comput. Human Behav., vol. 49, pp. 272-281, Aug. 2015, doi: 10.1016/j.chb.2015.03.022.

[10] V. Venkatesh, R. H. Smith, M. G. Morris, G. B. Davis, F. D. Davis, and S. M. Walton, 2003. "User Acceptance of Information Technology: Toward A Unified View,"

[11] M. D. Williams, N. P. Rana, and Y. K. Dwivedi, "The Unified Theory of Acceptance and Use of Technology (UTAUT): A Literature Review,” doi: 10.1108/JEIM-09-2014-0088.

[12] V. Venkatesh, J. Y. L. Thong, and X. Xu, 2012, "Consumer Acceptance and Use of Information Technology: Extending The Unified Theory of Acceptance and Use of Technology," MIS Q. Manag. Inf. Syst., Vol. 36, No. 1, pp. 157-178, doi: $10.2307 / 41410412$.

[13] A. Hasman, “An Introduction To Structural Equation Modeling," Stud. Health Technol. Inform., Vol. 213, No. May 2014, pp. 3-6, 2015, doi: 10.3233/978-1-61499-538-8-3.

[14] J. F. Hair, C. M. Ringle, and M. Sarstedt, "PLS-SEM: Indeed a Silver Bullet," J. Mark. Theory Pract., Vol. 19, No. 2, pp. 139-152, Apr. 2011, doi: 10.2753/MTP10696679190202.

[15] J. F. Hair, M. Sarstedt, L. Hopkins, and V. G. Kuppelwieser, "Partial Least Squares Structural Equation Modeling (PLS-SEM): An Emerging Tool In Business Research," European Business Review, Vol. 26, No. 2. Emerald Group Publishing Ltd., pp. 106121, Mar. 04, 2014, doi: 10.1108/EBR-10-2013-0128.

[16] G. García Botero, F. Questier, S. Cincinnato, T. He, and C. Zhu, "Acceptance and Usage of Mobile Assisted Language Learning by Higher Education Students, ” J. Comput. High. Educ., Vol. 30, No. 3, pp. 426-451, Dec. 2018, doi: 10.1007/s12528-018-9177-1. 
[17] S. Hao, V. P. Dennen, and L. Mei, "Influential Factors For Mobile Learning Acceptance Among Chinese Users," Educ. Technol. Res. Dev., Vol. 65, No. 1, pp. 101-123, Feb. 2017, doi: 10.1007/s11423-016-9465-2.

[18] A. Chavoshi and H. Hamidi, "Social, Individual, Technological and Pedagogical Factors Influencing Mobile Learning Acceptance In Higher Education: A Case from Iran," Telemat. Informatics, Vol. 38, pp. 133-165, May 2019, doi: 10.1016/j.tele.2018.09.007.

[19] T. Buchanan, P. Sainter, and G. Saunders, 2013, "Factors Affecting Faculty Use of Learning Technologies: Implications for Models of Technology Adoption," J. Comput. High. Educ., Vol. 25, No. 1, pp. 1-11, doi: 10.1007/s12528-013-9066-6.

[20] Y. K. Dwivedi, N. P. Rana, H. Chen, and M. D. Williams, 2011, "A Meta-Analysis of The Unified Theory of Acceptance and Use of Technology (UTAUT)," in IFIP Advances in Information and Communication Technology, Vol. 366, pp. 155-170, doi: 10.1007/978-3-642-24148-2_10.

[21] A. Raman and Y. Don, 2013, "Preservice Teachers' Acceptance of Learning Management Software: An Application of The UTAUT2 Model," Int. Educ. Stud., Vol. 6, No. 7, doi: 10.5539/ies.v6n7p157.

[22] N. U. Ain, K. Kaur, and M. Waheed, "The Influence of Learning Value On Learning Management System Use: An Extension of UTAUT2,” Inf. Dev., Vol. 32, No. 5, pp. 1306-1321, Nov. 2016, doi: 10.1177/0266666915597546.

[23] M. Đurišić and M. Bunijevac, 2017. "Parental Involvement Us A Important Factor for Successful Education,"

[24] F. Liu and C. Cavanaugh, 2020. "Success In Online High School Biology: Factors Influencing Student Academic Performance," Q. Rev. Distance Educ., Vol. 12, No. 1, pp. 37-55, Mar. 2011, Accessed: Dec. 28, [Online]. Available: https://go.gale.com/ps/i.do?

[25] G. Makrooni, "Being A First-Generation Migrant Family Student In Finland: Perceptions and Experiences of The Educational Journey To Higher Education," J. Ethn. Cult. Stud., Vol. 6, No. 3, pp. 157-170, 2019, doi: 10.29333/ejecs/293.

[26] S. Woofter, "Book Review: Building Equity: Policies and Practices to Empower All Learners,” Am. J. Qual. Res., Vol. 3, No. 1, pp. 136-139, Jun. 2019, doi: $10.29333 /$ ajqr/5815.

[27] M. Hubalovska, 2015, "Implementation of E-learning at Primary School Education," Recent Adv. Educ. Technol., pp. 74-79, Accessed: Dec. 21, 2020. [Online]. Available: http://www.inase.org/library/2015/zakynthos/bypaper/EDU/EDU-13.pdf. 
[28] S. A. Raza, W. Qazi, K. Akram Khan, and J. Salam, "Social Isolation and Acceptance of the Learning Management System (LMS) in The Time of COVID-19 Pandemic: An Expansion of The UTAUT Model," J. Educ. Comput. Res., Vol. 59, No. 2, pp. 183-208, 2021, doi: 10.1177/0735633120960421.

[29] M. Al-Okaily, H. Alqudah, A. Matar, and A. Lutfi, 2020, "Impact of COVID-19 Pandemic on Acceptance of e-Learning System in Jordan: A Case of Transforming The Traditional Education Systems Co-movement of Emerging Stock Markets: An Wavelet Coherency Analysis View Project," doi: 10.18510/hssr.2020.8483.

[30] R. Madigan, T. Louw, M. Wilbrink, A. Schieben, and N. Merat, "What Influences The Decision to Use Automated Public Transport? Using UTAUT to Understand Public Acceptance of Automated Road Transport Systems," Transp. Res. Part F Traffic Psychol. Behav., Vol. 50, pp. 55-64, Oct. 2017, doi: 10.1016/j.trf.2017.07.007.

[31] P. Tak and S. Panwar, "Using UTAUT 2 Model to Predict Mobile App Based Shopping: Evidences from India,” J. Indian Bus. Res., Vol. 9, No. 3, pp. 248-264, Aug. 2017, doi: 10.1108/JIBR-11-2016-0132.

[32] G. Silinskas and E. Kikas, 2019, "Parental Involvement in Math Homework: Links to Children's Performance and Motivation," Scand. J. Educ. Res., Vol. 63, pp. 17-37, doi: 10.1080/00313831.2017.1324901.

[33] R. Novianti and M. Garzia, "Parental Engagement in Children's Online Learning During COVID-19 Pandemic," J. Teach. Learn. Elem. Educ., Vol. 3, No. 2, pp. 117131, Jul. 2020, doi: 10.33578/jtlee.v3i2.7845.

[34] A. Lathrop, 2011. "Impact of Student Motivation in Online Learning Activities," Accessed: Apr. 19, 2021. [Online]. Available: https://digitalcommons.unl.edu/agronhortdiss/24.

[35] S. N. Attuquayefio and H. Addo, 2014. "Using The UTAUT Model to Analyze Students' ICT Adoption,” Int. J. Educ. Dev. Using Inf. Commun. Technol., Vol. 10, pp. 75-86, 